The rhizosphere is a micro ecological zone in direct proximity of plant roots. The German microbiologist, Hiltner (1904) ISSN 0974-7907 (Online) ISSN 0974-7893 (Print) introduced the concept of rhizosphere. The rhizosphere is OPEN ACCESS defined as the zone closer to plant (c) (i) roots with particulate matter and microbes. The zone away from the plant root system, not directly associated with the plant is non-rhizosphere. Theoretical extent of the rhizosphere is dependent on the zone of influence of the plant roots and associated microorganisms. The rhizosphere only extends a few millimeters from the root surface, and may thus appear as an insignificant proportion of the soil environment. When considering the total root length estimated to be about $700 \mathrm{~mm}$ for a single wheat plant (Bolton \& Fredrickson 1993), Khairnar \& Saler (1985) found high fungal population in rhizosphere under natural habitat. The highest number of microfungi in rhizosphere soil in some angiosperms has been reported by Sharma \& Bohra (2001) and Basumatry et al. (2005). Yasmeen \& Saxena (1990) explored rhizosphere and rhizoplane mycoflora of Adiantum incisum Forsk. Bohra \& Sharma (2007) have studied the rhizosphere and non-rhizosphere mycoflora of some ferns from Rajasthan. Bharati \& Pravesh (2012) explored rhizosphere and non-rhizosphere mycoflora associated with Lygodium flexuosum (L.) Sw. and Ampelopteris prolifera (Retz.) Copel. from Ranchi District of Jharkhand.

In Kolhapur District, Anogramma leptophylla (L.) Link and Hypodematium crenatum (Forssk.) Kuhn. are only restricted to small pockets at Panhala Fort (Images 1-3). The present paper deals with studies on rhizosphere and

\section{RHIZOSPHERE AND NON-RHIZOSPHERE MYCOFLORA OF TWO FERNS FROM PANHALA FORT, KOLHAPUR, MAHARASHTRA, INDIA}

\author{
P.R. Hande ${ }^{1} \&$ M.M. Dongare ${ }^{2}$ \\ ${ }^{1,2}$ Department of Botany, Shivaji University Kolhapur, Kolhapur, \\ Maharashtra 416004, India \\ ${ }^{1}$ hande.pavan@yahoo.com (corresponding author), \\ ${ }^{2}$ meena_dongare@yahoo.com
}

non-rhizosphere mycoflora associated with these ferns.

Materials \& Methods: Site: Panhala is one of the famous forts in Maratha Empire history, located in Panhala Village, $20 \mathrm{~km}$ northwest of Kolhapur in Maharashtra, India. It is situated between $16^{\circ} 48^{\prime} 31^{\prime \prime} \mathrm{N}$ $\& 74^{\circ} 6^{\prime} 29^{\prime \prime} \mathrm{E}$ and a maximum elevation of $968 \mathrm{~m}$. It is a well-known hill station. The annual temperature ranges between $20-32{ }^{\circ} \mathrm{C}$ and annual rainfall is around $261 \mathrm{~mm}$.

Sampling: The rhizosphere and non-rhizosphere soils of both the ferns were collected in August 2013, by the method suggested by Bohra \& Sharma (2007). The plants were uprooted and slightly shaken to remove bulk soil after which rhizosphere soil was collected in new zip lock polythene bags by tapping. Non-rhizosphere soil was collected in separate bags with the help of a sterilized trowel. The bags were then sealed, labeled and brought to the laboratory. They were kept at $4^{\circ} \mathrm{C}$ until the analysis.

Isolation: A microbial suspension was used to study the non-rhizosphere and rhizosphere mycoflora. The method adopted for this work was according to Johnson et al. (1959). To eliminate bacterial growth and better fungal separation, rose Bengal dye $(66.7 \mathrm{mg} / \mathrm{L})$ and streptomycin $(30 \mathrm{mg} / \mathrm{L})$ were added to potato dextrose agar (PDA) medium (Smith \& Dawson 1944). The

DOI: http://dx.doi.org/10.11609/jott.1642.8.3.8638-8640

Editor: R.K. Verma, Tropical Forest Research Institute, Jabalpur, India.

Date of publication: 26 March 2016 (online \& print)

Manuscript details: Ms \# 1642 | Received 24 November 2014 | Final received 22 January 2016 | Finally accepted 13 March 2016

Citation: P.R. Hande \& M.M. Dongare (2016). Rhizosphere and non-rhizosphere mycoflora of two ferns from Panhala Fort, Kolhapur, Maharashtra, India. Journal of Threatened Taxa 8(3): 8638-8640; http://dx.doi.org/10.11609/jott.1642.8.3.8638-8640

Copyright: () Hande \& Dongare 2016. Creative Commons Attribution 4.0 International License. JoTT allows unrestricted use of this article in any medium, reproduction and distribution by providing adequate credit to the authors and the source of publication.

Funding: None.

Conflict of Interest: The authors declare no competing interests.

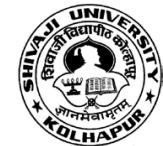

Acknowledgments: Authors are thankful to Prof. Dr. S.R. Yadav, The Head, department of Botany for providing lab facilities and also thankful to Prof. Dr. S.S. Kamble for valuable suggestions. 


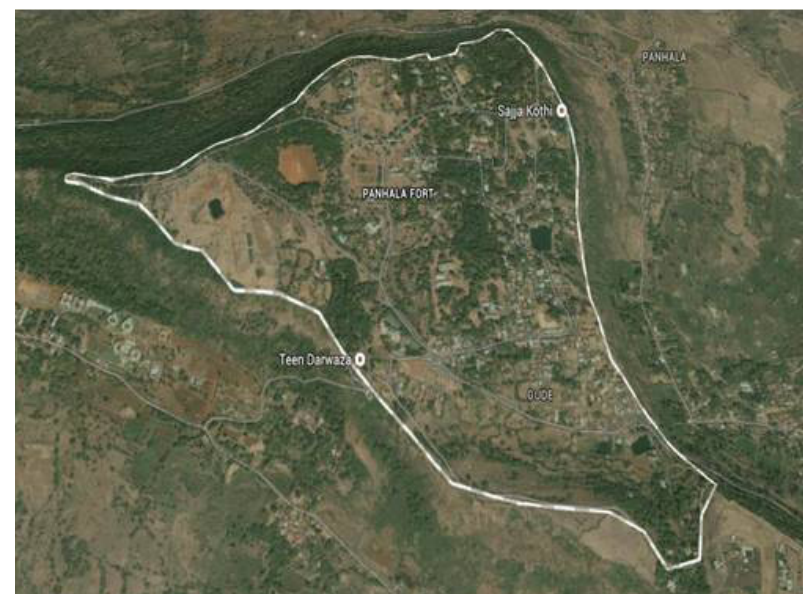

Image 1. Study site: Panhala Fort

autoclaved cool medium was poured in autoclaved petriplates. $1 \mathrm{~g}$ of soil was weighed and three dilutions viz., 1:100, 1:1000 and 1:10000 were prepared in sterile distilled water. The soil solutions were shaken well to homogenize and after settling down, $1 \mathrm{ml}$ aliquot was pipetted out in separate sterilized petriplates containing PDA medium. The aliquot was spread evenly on agar surface in each petriplate. Three replicates of each dilution were taken and were incubated at $28^{\circ} \mathrm{C} \pm 2^{\circ} \mathrm{C}$ for 7-10 days. The plates were then examined for plate count. Colony forming unit and rhizosphere effect were calculated as suggested by Nagamani et al. (2006) and Starkey (1938).

Identification of fungi: The microscopy and micrometry was done. The fungi were identified after Gilman (1945), Barnett \& Hunter (1973), Watanabe (2002), Nagamani et al. (2006).

Results and Discussion: In the present study, fungal species found in non-rhizosphere were more as compared to rhizosphere of both the ferns. Higher percentage of fungal species was shown by $\mathrm{H}$. crenatum (Forssk.) Kuhn $44.5 \%$ in non-rhizosphere and $27.77 \%$ in rhizosphere. Lower percentage of fungal species was found in A. leptophylla, i.e., 38.88\% in non-rhizosphere and $16.66 \%$ in rhizosphere. Aspergillus was found to be dominant among the fungal population in soil samples (Table 1, Fig. 1). Number of fungal propagules present per gram of soil (CFU) was more in non-rhizosphere of A. leptophylla measuring $3.9 \times 10^{5}$. Whereas CFU in nonrhizosphere of $H$. crenatum was less, up to $1.7 \times 10^{5}$ (Fig. 2 ). While considering rhizosphere effect, i.e., $R / S$ ratio, A. leptophylla had 0.71 and that of $H$. crenatum was 1.56 (Fig. 3). Clearly indicating that $A$. leptophylla has suppressive effect and $H$. crenatum has stimulatory effect on the soil fungi. Abdel-Hafez (1982) recorded greater

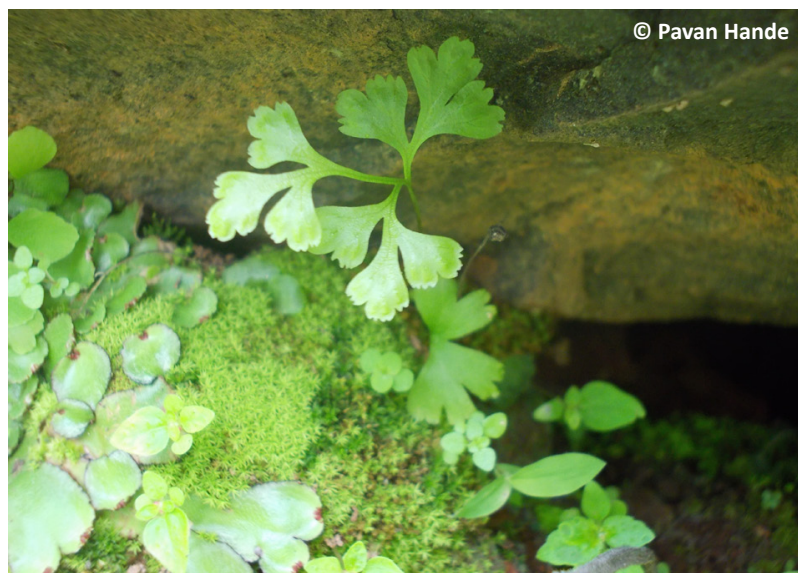

Image 2. Anogramma leptophylla (L.) Link.

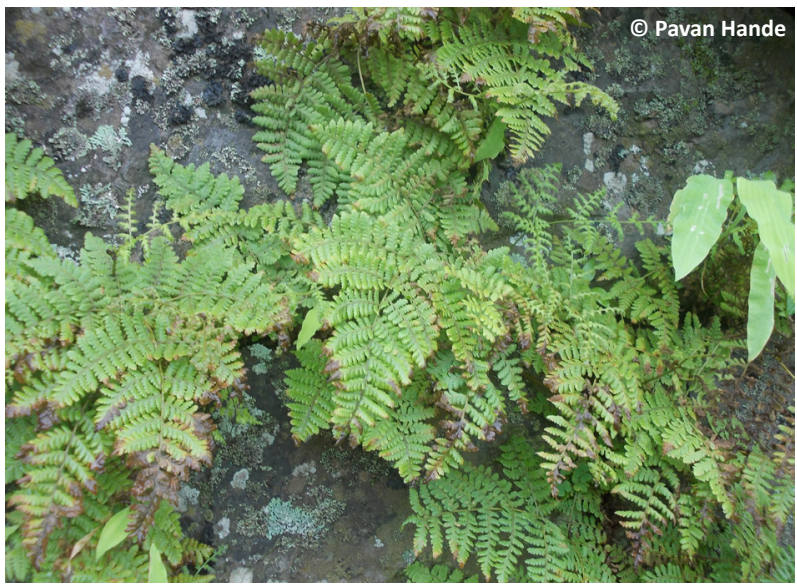

Image 3. Hypodematium cernatum Forssk. Kuhn

diversity of fungi occurring in the non-rhizosphere than in the rhizosphere. According to Sullia (1973) rhizosphere having the lowest fungal association, may be due to antifungal root exudates in higher plants. The inhibitory effect on the growth of fungi in rhizosphere may be due to some antimicrobial compounds present in the ferns (Bharti \& Pravesh 2012). Yasmeen (1989), Yasmeen \& Saxena (1990), Gupta et al. (1991), Bohra \& Sharma (2007) have also observed almost similar results, while Khairnar \& Saler (1985) found high fungal population in rhizosphere under natural habitat. Sharma \& Bohra (2001), Basumatary et al. (2005), have also reported that the number of micro-fungi was highest in rhizosphere soil in some angiosperms.

\section{References}

Abdel-Hafez, S.I.I. (1982). Rhizosphere and rhizoplane fungi of Triticum vulgare cultivated in Saudi Arabia. Mycopathologia 78: 79-86.

Basumatary, S.K., M. Ahmed \& A. Rahman (2005). Rhizospheric and 


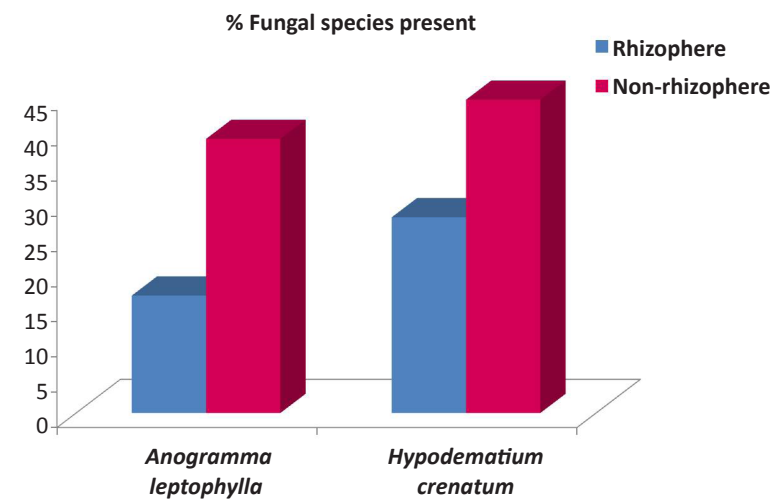

Figure 1. Percentage of fungal species present

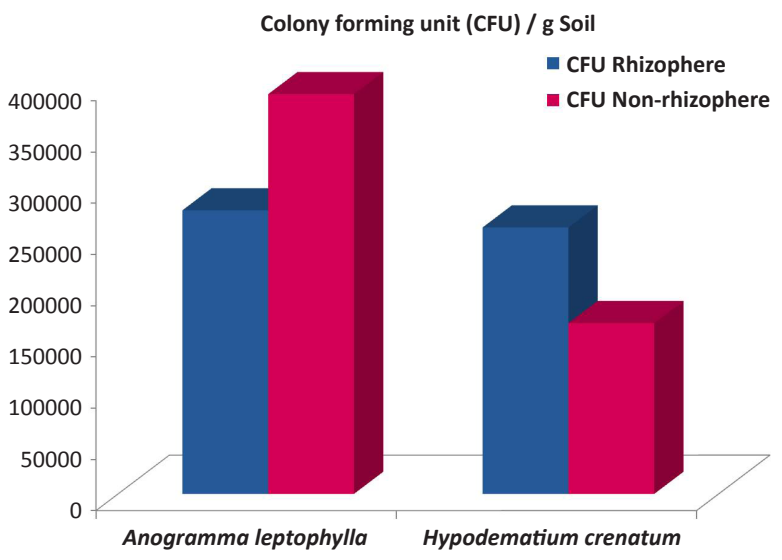

Figure 2. Colony forming units (CFU)/g soil

non-rhizospheric micro fungi of medicinal plant Nayontara (Vinca rosea). Plant Archives 5(1): 313-314.

Barnett, H.L. \& B.B. Hunter (1987). Illustrated Genera of Imperfect Fungi. Mac Millan Publ. Co., New York.

Bohra, R.D. \& S. Sharma (2007). Rhizosphere and rhizoplane mycoflora of some ferns from Rajasthan. Indian Fern Journal 24: 125-131.

Bolton, H. Jr. \& J.K. Fredrickson (1993). Microbial Ecology of the Rhizosphere, pp. 27-57. In: Meeting, F.B. Jr. (ed.). Soil Microbial Ecology. Marcel Dekker, New York.

Gilman, J.C. (1957). A Manual of Soil Fungi - $2^{\text {nd }}$ Edition. Iowa State Coll. Press, Ames.

Hiltner, L. (1904). Überneue Erfahrungen und Probleme auf dem Gebiet der Boden bakteriologie unterbesonderer Berücksichtigung der Gründüngung und Brache. Arbeiten der Deutschen Landwirtschaftlichen. Gesellschaft 98: 59-78.

Johnson, L.F., E.A. Curl, J.H. Bond \& H.A. Fribourg (1959). Methods for Studying Soil Microflora-Plant Disease Relationships. Burgess Publishing Company, Minneapolis, MN, USA, 178pp.

Khairnar, D.N. \& R.S. Saler (1985). Rhizosphere mycoflora of some ferns from Satmala hills. Geobios New Reports 4: 37-40.

Nagamani, A., I.K. Kunwar \& C. Manoharachary (2006). Hand Book of Soil Fungi. I.K. International Pvt. Ltd., India.

Sharma, S. \& A. Bohra (2001). Comparison of rhizosphere and rhizoplane microflora of leguminous plants growing in western Rajasthan. Advances in Plant Sciences 14(1): 275-278.

Starkey, R.L. (1938). Some influences of the development of higher plants upon the microorganisms in the soil VI. Microscopic examination of the rhizosphere. Soil Science 45: 207-249.

Sullia, S.B. (1973). Effect of root exudates and extracts on rhizosphere

Table 1. Fungal population associated with Anogramma leptophylla and Hypodematium crenatum

\begin{tabular}{|c|l|c|c|c|c|}
\hline \multirow{2}{*}{} & \multirow{2}{*}{ Fungal species } & \multicolumn{2}{c|}{$\begin{array}{c}\text { Anogramma } \\
\text { leptophylla }\end{array}$} & \multicolumn{2}{c|}{$\begin{array}{c}\text { Hypodematium } \\
\text { crenatum }\end{array}$} \\
\cline { 2 - 6 } & & $\mathrm{R}$ & $\mathrm{N}-\mathrm{r}$ & $\mathrm{R}$ & $\mathrm{N}-\mathrm{r}$ \\
\hline 1 & Absidia cylindrospora & - & - & + & - \\
\hline 2 & Aspergillus candidus & - & - & - & + \\
\hline 3 & A. carbonius & - & - & - & + \\
\hline 4 & A. flavus & - & + & - & - \\
\hline 5 & A. fumigates & + & + & - & - \\
\hline 6 & A. humicola & - & + & - & - \\
\hline 7 & A. niger & - & + & + & - \\
\hline 8 & Aspergillus sp. & - & - & + & - \\
\hline 9 & Fusarium sp. & + & - & - & + \\
\hline 10 & Gray mycelium & - & - & - & + \\
\hline 11 & Mucor sp. & + & - & - & - \\
\hline 12 & Penicillium reticulosum & - & + & + & - \\
\hline 13 & Penicillium rugulosum & - & - & - & + \\
\hline 14 & Rhizopus oryzae & - & - & - & + \\
\hline 15 & Trichocladium sp. & - & + & - & - \\
\hline 16 & Unidentified & - & - & + & - \\
\hline 17 & Cuvularia sp. & - & - & - & + \\
\hline 18 & White Mycelium & - & + & - & + \\
\hline$\%$ Fungal species Present & 16.66 & 38.88 & 27.77 & 44.44 \\
\hline & & & - & & + \\
\hline
\end{tabular}

R - Rhizosphere; N-r - Non-rhizosphere

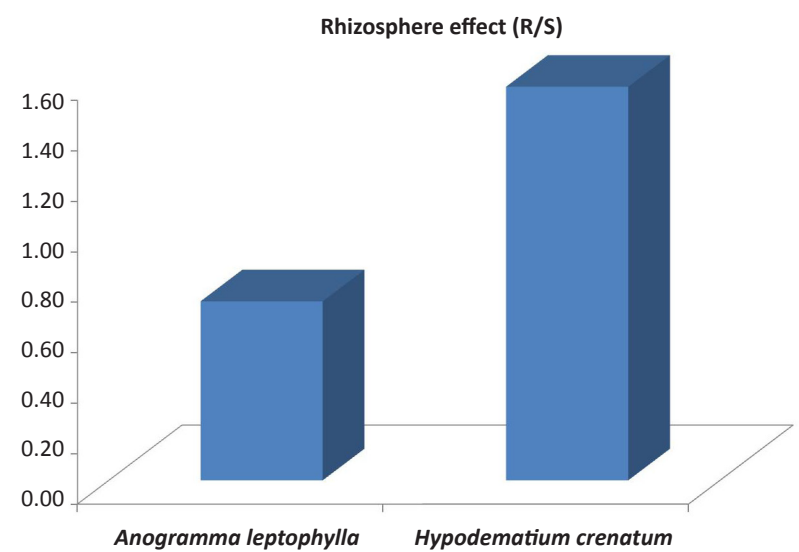

Figure 3. Rhizosphere effect $(\mathrm{R} / \mathrm{S})$

fungi. Plant and Soil 39(1): 197-200.

Yasmeen (1989). Rhizosphere mycoflora of some cultivated ferns. Pakistan Journal of Scientific and Industrial Research 32(6): 421

Yasmeen \& S.K. Saxena (1990). Rhizosphere and rhizoplane mycoflora of Adiantum incisum. Indian Fern Journal 7: 21-23.

Watanabe, T. (2002). Pictorial Atlas of Soil and Seed Fungi: Morphologies of Cultured Fungi and Key to Species. Lewis Publishers (CRC Press LLC), Boca Raton, Florida, USA. 